\title{
Dating the Cambrian Purley Shale Formation, Midland Microcraton, England
}

\author{
MARK WILLIAMS*†, ADRIAN W. A. RUSHTON \\ JAN ZALASIEWICZ*, ADAM P. MARTINף, DANIEL J. CONDONף\& \\ PAUL WINROW\| \\ * Department of Geology, University of Leicester, Leicester LE1 7RH, UK \\ $\ddagger$ British Geological Survey, Keyworth, Nottinghamshire NG12 5GG, UK \\ $\S 75$ Church Lane, Nuneaton, Warwickshire CV10 0EY, UK \\ ףNERC Isotope Geosciences Laboratory, British Geological Survey, Keyworth, Nottingham NG12 5GG, UK \\ \|Department of Earth Science and Engineering, Imperial College London, South Kensington Campus, \\ London SW7 2AZ, UK
}

(Received 12 September 2012; accepted 21 December 2012; first published online 3 May 2013)

\begin{abstract}
Zircons from a bentonite near the base of the Purley Shale Formation in the Nuneaton area, Warwickshire, yield a ${ }^{206} \mathrm{~Pb} /{ }^{238} \mathrm{U}$ age of $517.22 \pm 0.31 \mathrm{Ma}$. Based on the fauna of small shelly fossils and the brachiopod Micromitra phillipsii in the underlying Home Farm Member of the Hartshill Sandstone Formation, trilobite fragments that are questionably referred to Callavia from the basal Purley Shale Formation, and the presence of trilobites diagnostic of the sabulosa Biozone $66 \mathrm{~m}$ above the base of the Purley Shale Formation, the bentonite likely dates an horizon within Cambrian Stage 3, at about the level of the Fallotaspis or basal Callavia Biozone. This is consistent with bentonite ages from other localities in southern Britain, which constrain the age of the lower and uppermost parts of Cambrian Stage 3. The new date provides additional chronological control on the earliest occurrence of trilobites in the Midland Microcraton, a date for the marine transgression at the base of the Purley Shale Formation, and is the first radiometric age from the Cambrian succession of Warwickshire.
\end{abstract}

Keywords: Cambrian, radiometric age, trilobites, Avalonia, stratigraphy, geochronology.

\section{Introduction}

The rock successions of southern Britain have proved important for calibrating a global Cambrian chronology (Rushton et al. 2011, fig. 1). The age of the lowermost Cambrian rocks in England and Wales are undetermined, but in Pembrokeshire, a thin bentonite from the Caerfai Bay Shales Formation, some $11 \mathrm{~m}$ above the top of the St Non's Sandstone Formation at Caerfai Bay, yielded an age of $519 \pm 1 \mathrm{Ma}$ (Landing et al. 1998; see Fig. 1), and has been cited in support of a minimum age of $521 \mathrm{Ma}$ for the base of Cambrian Series 2 (see Peng \& Babcock, 2008; Harvey et al. 2011). In Shropshire, Cambrian rocks have yielded dates that constrain the age of the Cambrian Series 2 Series 3 boundary (Harvey et al. 2011). A bentonite just below the top of the Green Callavia Sandstone yields an age of $514.45 \pm 0.36 \mathrm{Ma}$ (Harvey et al. 2011), which provides a maximum age for the boundary between Cambrian stages 3 and 4 (see Fig. 1), as provisionally recognised by Rushton et al. (2011, p. 3). A bentonite from within the basal Upper Comley Sandstone yields a $\mathrm{U}-\mathrm{Pb}$ date of $509.10 \pm 0.22 \mathrm{Ma}$ that provides a minimum age limit on the base of Series 3, and of Cambrian Stage 5 (Harvey et al. 2011; Fig. 1). This date provides constraint for the interpolated age of $510 \mathrm{Ma}$

†Author for correspondence: mri@le.ac.uk for the Series 2 - Series 3 boundary given by Peng \& Babcock (2008).

Here we report a newly analyzed bentonite layer from the lower part of the Purley Shale Formation in Warwickshire, England, which provides the first radiometric age for the Cambrian sedimentary succession of the Charnwood Block within the Midland Microcraton (see Rushton et al. 2011). The new age provides additional chronological control on the Cambrian succession of England and Wales, and provides new stratigraphic ties with the evolving global Cambrian chronology (Peng \& Babcock, 2008).

\section{Geological and stratigraphical setting}

The Charnwood Block is an integral component of the Avalon Composite Terrane (sensu Woodcock, 2011, p. 20 ), which was already assembled by early Cambrian times, and records part of the Cambrian succession of Avalonia. The Cambrian of the Charnwood Block is exposed in inliers in the Charnwood Forest area of Leicestershire, in the Nuneaton Inlier on the eastern edge of the Coventry Coalfield and in the small Dosthill Inlier on its western boundary fault, the latter two areas being in Warwickshire. Rushton (1974, pp. 105-13) gave a general summary of the stratigraphy in these inliers, with references to earlier work. More recent accounts that also refer to many borehole records are given in Bridge et al. (1998), Powell, Glover \& Waters, 

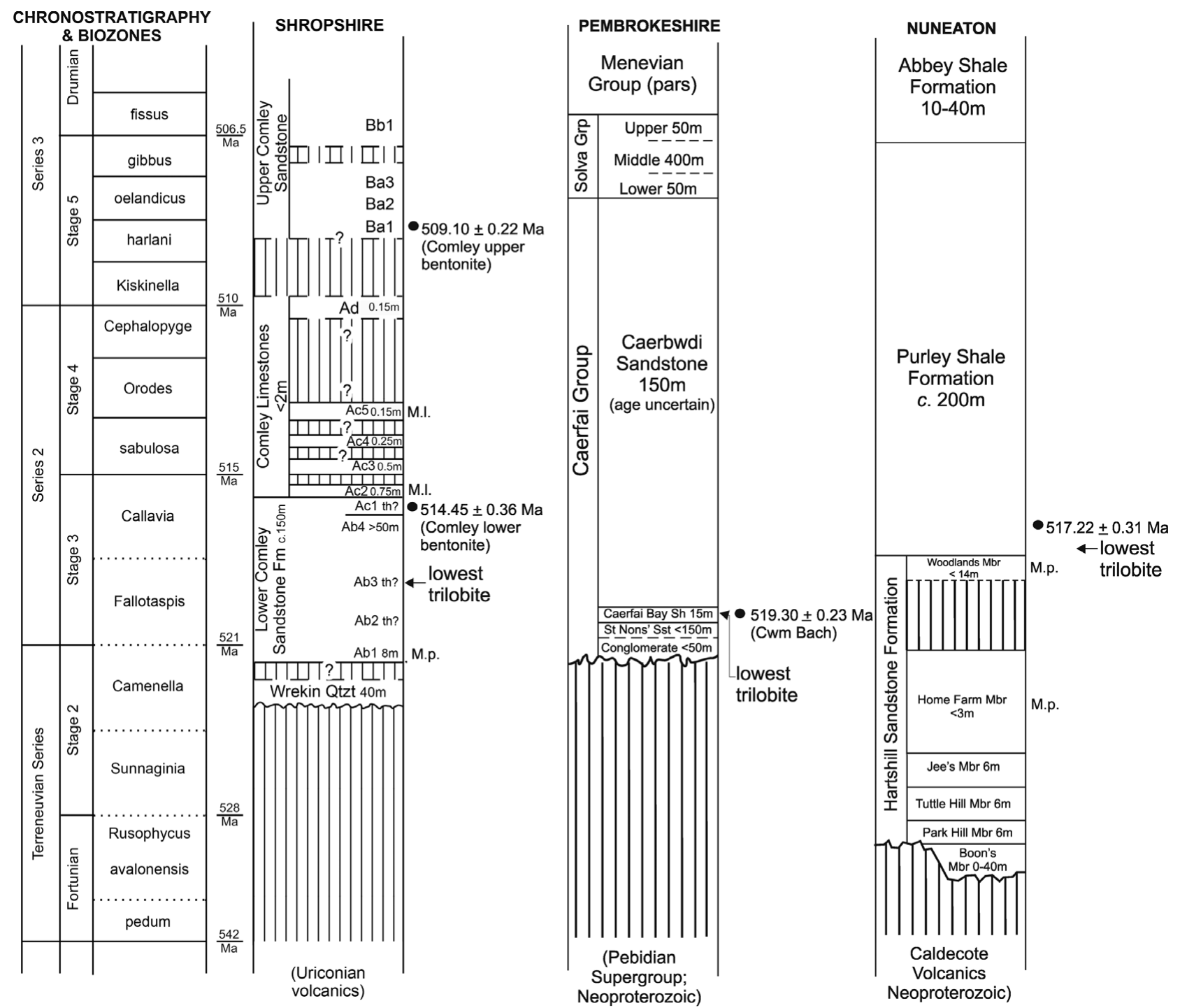

Figure 1. Stratigraphy of the Cambrian, Terreneuvian, Series 2 and Series 3 lithological succession for the Nuneaton area of Warwickshire and contemporaneous lithostratigraphic successions in Shropshire and Pembrokeshire, South Wales. Also shown are intervals from which radiometric dates have successfully been determined. Abbreviations: M.p. - Micromitra phillipsii; M.l. Micromitra labradorica; 'th' - thickness. The alphanumeric nomenclature for the Shropshire column is after Cobbold (1921). In the column for Shropshire, 'Comley upper bentonite' and 'Comley lower bentonite' are defined in Harvey et al. (2011). In the column for Pembrokeshire, the age of the Caerfai Bay Shales at 'Cwm Bach' is the bentonite locality reported by Harvey et al. (2011), which gives a comparable, but slightly more refined age to that of the bentonite at Caerfai Bay, which yielded an age of $519 \pm 1$ Ma to Landing et al. (1998).

(2000) and Rushton et al. (2011). Within the Charnwood Block, the Cambrian rocks of Nuneaton represent a relatively complete stratigraphical succession. The arenaceous lower divisions of the Hartshill Sandstone Formation (Fig. 1) are known from extensive quarry exposures and have been thoroughly studied (Brasier, 1989 and references therein), and the whole succession of the Stockingford Shale Group has (aside from some parts of the Purley Shale Formation) been studied from excavations and borehole cores (Taylor \& Rushton, 1971).

The six members of the Hartshill Sandstone Formation (Fig. 1) were described by Bridge et al. (1998, pp. 21-30). Brasier (1989, p. 87) showed that they were deposited in a variety of near-shore to offshore marine facies and recorded the presence of several trace fossils of Cambrian type. In the absence of body fossils, correlation of the lower four members, all of them arenaceous, is not very certain. The Home Farm Member is a condensed succession of thin fossiliferous calcareous and phosphatic units, bounded above and below by non-sequences. Brasier (1984, 1986, 1989) described the diverse fauna of small shelly fossils and discussed their correlation with the Bonavista Group (Terreneuvian) of SE Newfoundland, especially with the Cuslett Formation, and the overlying Fosters Point Formation (Landing \& Benus, 1988); he suggested correlation of the Home Farm Member with part of the Tommotian and the lowest part of the Atdabanian stages of the Siberian Platform. The uppermost division of the Hartshill Sandstone Formation, the Woodlands Member (Fig. 1), overlies a hard-ground and an inferred 
a b

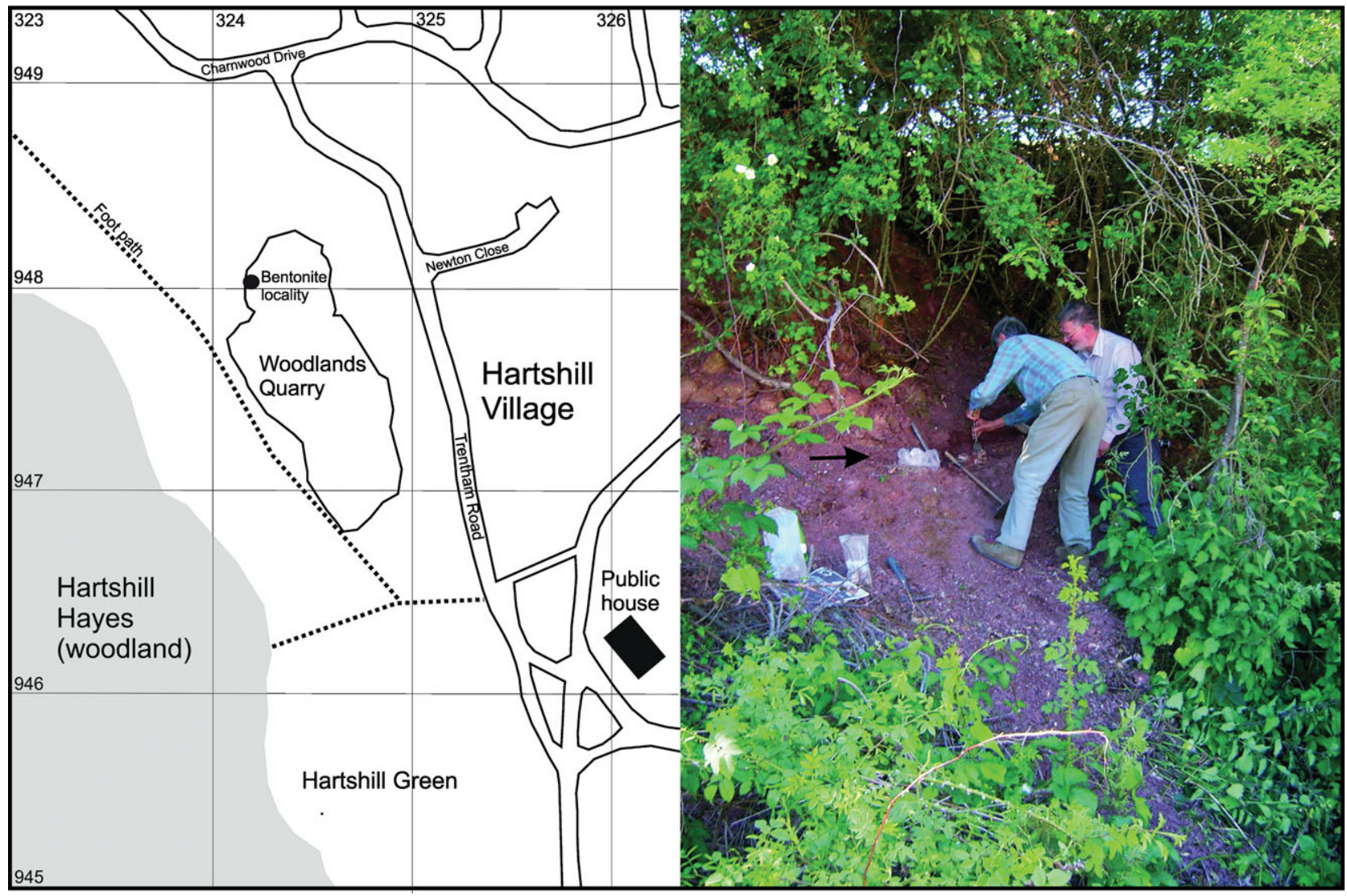

Figure 2. (Colour online) (a) Geographical position of the bentonite horizon in the NW corner of Woodlands Quarry. (b) The thin bentonite horizon (arrowed) in the basal Purley Shale Formation above the sill, Alan Cook (right) and Adrian Rushton for scale.

non-sequence at the top of the Home Farm Member, and appears locally to pass up rapidly into the succeeding Purley Shale Formation (Brasier, 1989, p. 90).

The Stockingford Shale Group was deposited on a stable but gently subsiding marine shelf, mainly below wave-base. It is divided into seven mudstone formations with thin sandstone beds at some levels, the Purley Shale Formation being the lowermost unit. Deposition appears to have been fairly continuous, apart from an important non-sequence proved in the upper part of Cambrian Series 3 between the Abbey Shale and Mancetter Shale formations, and the possibility of a hiatus in the mid-part of the Purley Shale Formation (see Rushton et al. 2011, p. 33, for further discussion). Agnostoids, eodiscid and polymerid trilobites and bradoriid arthropods occur almost throughout the succession and enable correlation with the successions in SE Newfoundland and the biozonal succession in Scandinavia.

\section{Sampled locality and horizon}

Woodlands Quarry, $200 \mathrm{~m}$ NNW of Hartshill Green (5 km NW of Nuneaton), exposes the top of the Hartshill Sandstone Formation, including the upper part of the Jee's Member, the Home Farm Member and the Woodlands Member, succeeded conformably by the basal part of the Purley Shale Formation, the basal contact of which is displaced by a minor cross-fault and complicated by a lamprophyre sill that is intruded into the lowest part of the Purley Shale Formation succession (Eastwood et al. 1923, p. 33). Quarrying has long ceased and the locality is now a Site of Special Scientific Interest or 'SSSI' (Rushton et al. 1999, p. 81) and is the stratotype for the Home Farm Member.

In the 1970s, after the quarry had been landscaped, a white clay bed about $2 \mathrm{~cm}$ thick was temporarily exposed near the base of the Purley Shale Formation in the SW face of the quarry; Adrian Rushton collected a small sample that, following analysis by C. R. Hallsworth at the British Geological Survey, was shown to be of volcanic origin. The west side of the quarry has since largely been levelled off and become overgrown. No bentonite can now be seen there, but in 2011 the present authors succeeded in sampling what is assumed to be the same bentonite bed at the northern end of the quarry (Fig. 2).

The new exposure of bentonite is situated in the NW corner of the Quarry at UK National Grid Reference SP 32417 94805, and at 113.5 to $114.5 \mathrm{~m}$ above Ordnance Datum (Lat. 52 $33^{\prime} 0.558^{\prime \prime} \mathrm{N}$, Long. $1^{\circ} 31^{\prime} 24.0564^{\prime \prime} \mathrm{W}$; Fig. 2). The bentonite is estimated to be $7 \mathrm{~m}$ stratigraphically above the base of the Purley Shale Formation, but at this locality a sill about $7 \mathrm{~m}$ thick, extending from a level about half a metre above the base of the formation to about $6.25 \mathrm{~m}$ below 
the level of the bentonite, makes the topographical separation from the base of the Purley Shale Formation to the bentonite bed about $14 \mathrm{~m}$.

\section{4. $\mathrm{U}-\mathrm{Pb}$ (zircon) geochronology: absolute age of the Purley Shale Formation bentonite}

All analyses were carried out at the NERC Isotope Geosciences Laboratory (NIGL). Prior to ID-TIMS (Isotope Dilution Thermal Ionisation Mass Spectrometry) analyses, zircons were subject to a modified version of the chemical abrasion technique (Mattinson, 2005). For details of sample pre-treatment, dissolution, anion exchange chemistry, mass spectrometry and data reduction at NIGL see Harvey et al. (2011) and references therein. Errors for $\mathrm{U}-\mathrm{Pb}$ dates are reported in the following format: $\mathrm{X}(\mathrm{Y})[\mathrm{Z}]$, where $\mathrm{X}$ is the internal or analytical uncertainty in the absence of all systematic error (tracer calibration and decay constants), Y includes the tracer calibration error (using an estimate of the 2 standard deviation of $0.05 \%$ for the $\mathrm{Pb} / \mathrm{U}$ ratio in the tracer), and $\mathrm{Z}$ includes the additional ${ }^{238} \mathrm{U}$ decay constant errors of Jaffey et al. (1971). These systematic errors are added, in quadrature, to the weighted mean internal error. All analytical uncertainties are calculated at the $95 \%$ confidence interval.

Nine optically clear zircon crystals extracted for chronology had a prismatic habit and pointed crystal terminations typical of magmatic zircon and were analyzed for $\mathrm{U}-\mathrm{Pb}$ geochronology (Table 1). Grains z6 and $\mathrm{z} 8$ yielded ${ }^{206} \mathrm{~Pb} /{ }^{238} \mathrm{U}$ ages of 1293.3 and $620.7 \mathrm{Ma}$ that are interpreted as xenocrystic. Concordant grains z5 and z7 yielded ${ }^{206} \mathrm{~Pb} /{ }^{238} \mathrm{U}$ ages of $518.4 \mathrm{Ma}$ that are slightly older than the eruption age (Fig. 3) suggesting a prolonged pre-eruptive magmatic history. The ages of five zircon grains (z1-4 and z12) are equivalent within error and yielded a ${ }^{206} \mathrm{~Pb} /{ }^{238} \mathrm{U}$ age of 517.22 $\pm 0.31(0.40)[0.66] \mathrm{Ma}(\mathrm{MSWD}=0.67$; probability of fit $=0.61)$. This is taken as the preferred eruption age of this tuff and the emplacement age at this stratigraphic level (Fig. 1).

\section{Biostratigraphy and correlation}

Faunas are recorded below the bentonite horizon, principally from the Home Farm Member of the Hartshill Sandstone Formation (Fig. 1). The oldest identifiable fossils that overlie the bentonite are from Locality 1 of Rushton (1966, p. 4), which is estimated to lie about $60 \mathrm{~m}$ above the bentonite layer.

\section{5.a. Home Farm Member}

Brasier (1984, p. 230) recognised six faunal assemblages from the Home Farm Member, in ascending order numbers I-VI, and listed their constituent taxa. Assemblage V, with around 30 taxa, is particularly rich and diverse; it has species in common with faunas from Scandinavia and Siberia, in particular with faunas

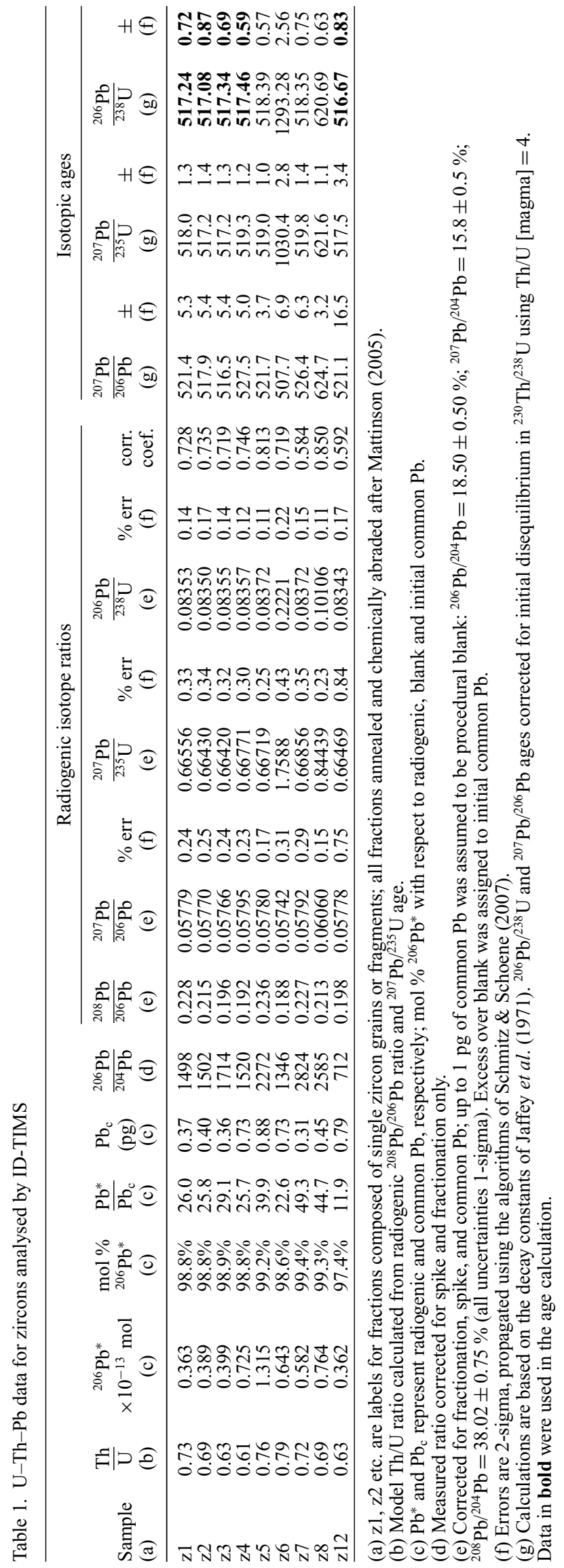




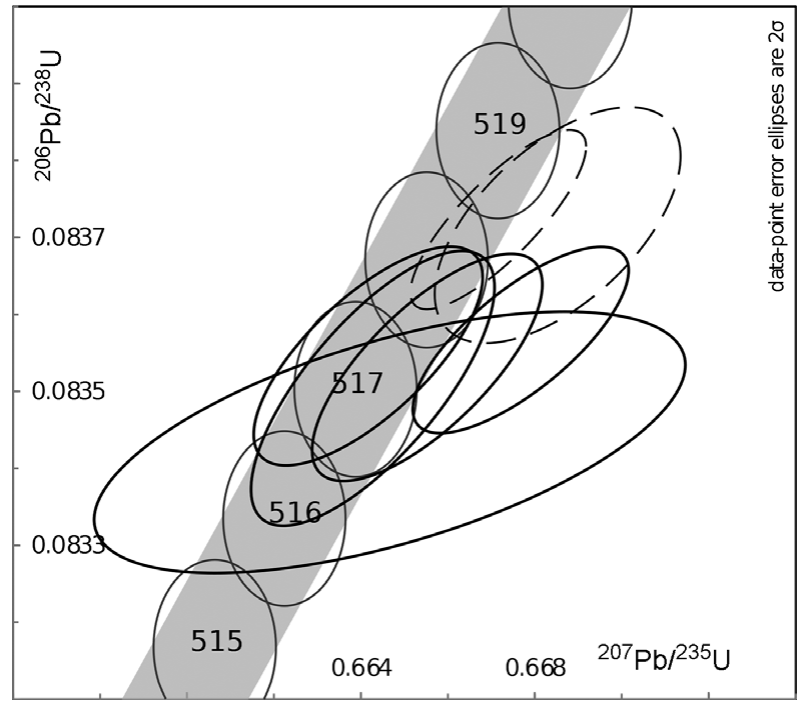

Figure 3. Conventional concordia plot for zircons from the Purley Shale Formation for single zircon grains analysed by the ID-TIMS method. The dashed ellipses show grains z5 and z7 that were not used in the age calculation.

near the Tommotian-Atdabanian boundary, and with eastern Canada, such as those of the Camenella baltica Biozone of the successions in Cape Breton Island and Newfoundland (Landing, 1991, 1995, 1996). Brasier's (1984) Assemblage VI extends up to the basal bed of the Woodlands Member; it is much less diverse, but includes some persistent, mainly tubular, fossils such as Coleoloides, Hyolithellus and Torellella that range up from lower assemblages.

\section{5.b. Woodlands Member}

Brasier's (1984) Assemblage VII is a sparse fauna with Coleoloides typicalis and Torellella sp., collected from thin calcareous lenses at the top of the Woodlands Member (Fig. 1).

\section{5.c. Purley Shale Formation}

In 1912 the Geological Survey collected fragments of trilobites from calcareous nodules $0.3 \mathrm{~m}$ above the base of the Purley Shale Formation at Camp Hill Grange Quarry, $1.4 \mathrm{~km}$ SE of Woodlands Quarry, which was formerly a good section (Pringle, 1913; Eastwood et al. 1923, p. 33) but was subsequently filled in. The trilobite fragments were identified as Callavia? by Smith \& White (1963, p. 401) and are the earliest record of trilobites from the Charnwood Block. Rushton (1966, p. 37) collected a cephalic fragment from the same locality and horizon and identified it with doubt also as Callavia?, and additionally recorded trilobite fragments from the same horizon at Woodlands Quarry. The whereabouts of the material recorded by Illing (1913, p. 452) from a horizon $12 \mathrm{~m}$ above the base of the Purley Shale Formation at Stoneleigh Quarry '200 yards (c. $184 \mathrm{~m}) \mathrm{S}$ of Worthington Farm' (at SP 3200 9557) has not been ascertained. Brasier et al. (1978), who investigated a larger range of localities (including the working quarries to the SE of Hartshill), added greatly to the fauna by studying acid-insoluble residues from the calcareous deposits. Brasier's (1984) Assemblage VIII, from calcareous nodules $1.5 \mathrm{~m}$ above the base of the Purley Shale Formation, contains Callavia?, Coleoloides typicalis, sponge spicules, conodonts?, Platysolenites antiquissimus and Teichichnus burrows (Brasier, 1989).

All of the above workers have noted the appearance of trilobite fragments just above the base of the Purley Shale Formation, but they are not identifiable to species level and are only doubtfully compared to Callavia (Fig. 4). It is suspected that the appearance of trilobite fragments is linked to the rapid change to more open marine facies from the Woodlands Member to the Purley Shale Formation, which Brasier (1989, p. 87) plausibly envisaged as partly lateral equivalents. In the Cambrian correlation report (Rushton et al. 2011, p. 6) the first appearance of trilobites was adopted as a criterion for the recognition of the base of Series 2 of the Cambrian, but it was recognized also that the lowest trilobite biozones might overlap with the Camenella baltica Biozone at the top of the first Cambrian Series, the Terreneuvian.

\section{Biostratigraphic significance of Micromitra}

The fauna from the Home Farm Member of the Hartshill Sandstone Formation contains the brachiopod Micromitra phillipsii, characterized by a small, ventral posteriorly projecting knob, a long straight hinge line and rounded postero-lateral angles (see Cobbold, 1919; and Brasier, 1984, 1986). Holl (1865) originally described M. phillipsii from the Hollybush Sandstone of the Malvern area and the lectotype was re-figured by Cocks (2008, pl. 1, fig. 15). Matley (1902) recorded M. phillipsii from the underlying Malvern Quartzite as well as the Hollybush Sandstone, whose age, based on acritarchs, was discussed by T. L. Potter (in Rushton et al. 2011, p. 31); a recent review of this material has confirmed Matley's identification. In the Nuneaton area, M. phillipsii occurs in the Home Farm Member and also the Hartshill Sandstone Formation at the base of the Home Farm Member, ranging up to Bed 10ii of Brasier (1989, fig. 5.6). Elsewhere in England $M$. phillipsii is recorded in the lower Cambrian Obolella groomi grits of Shropshire (Cobbold, 1921; at the Ab1 horizon of Cobbold, see Fig. 1). Although Hinz (1987) recorded ' $M$. phillipsi' from the somewhat younger Comley Limestones (see Fig. 1), those specimens are not considered to represent $M$. phillipsii as they appear to lack the characteristic knob.

In England, M. phillipsii appears to be characteristic of the Camenella Biozone and is not known to range up to the level of the oldest trilobites. Landing (1991, 1995) recorded M. phillipsii from the lower Cambrian Avalonian successions in Cape Breton, Newfoundland, the Cuslett Formation and the Fosters Point Formation 

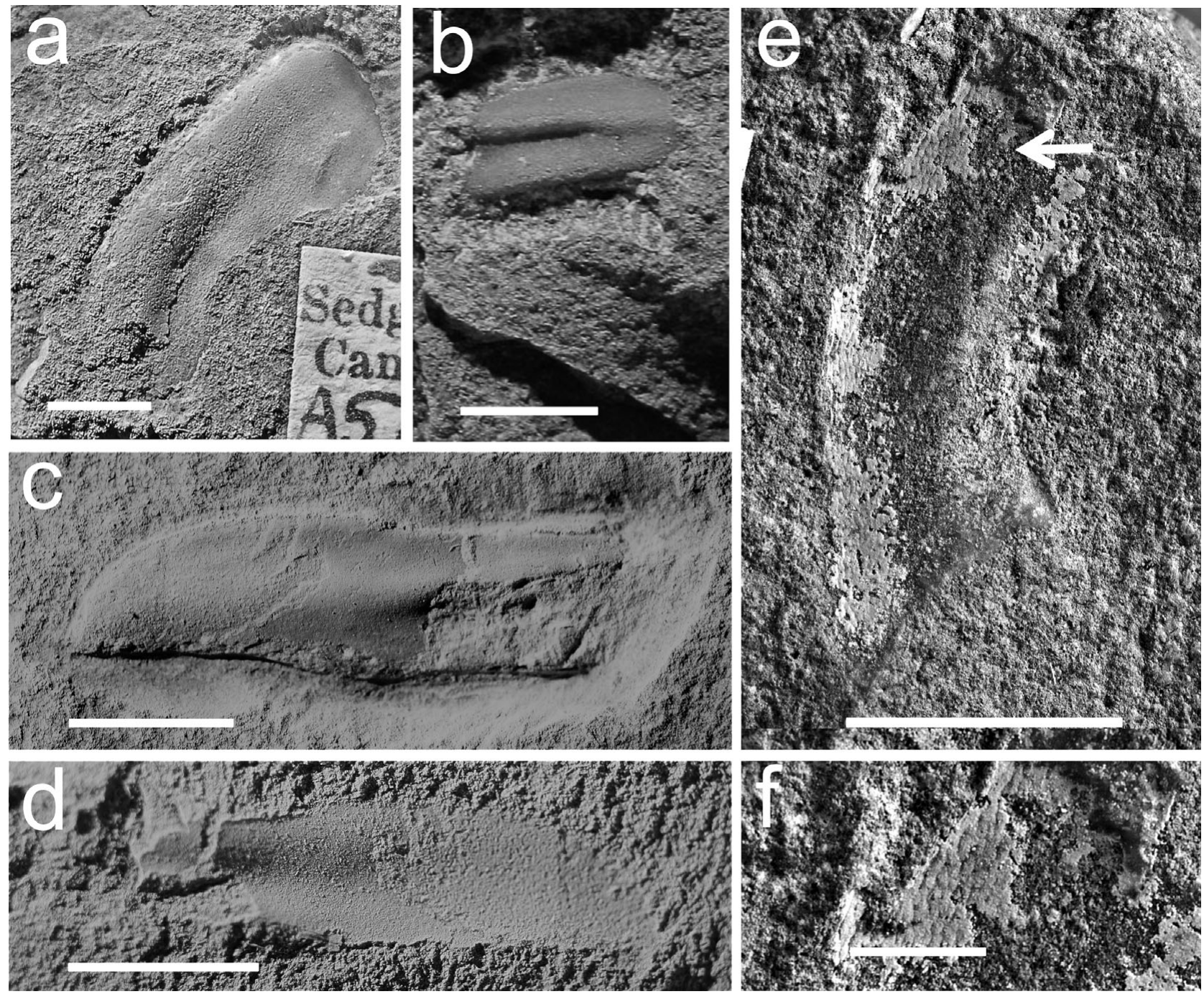

Figure 4. Trilobites. (a, e, f) Cephalic fragment from Camp Hill Grange Quarry; (a) internal mould, SM A.57266a; (e) the counterpart (SM A.57266b) of the same shows sculpture that resembles that at the edge of the cephalic shield of Callavia callavei from the Comley Limestones (arrowed); (f) part of the same, enlarged. (b) Pleural fragment from Woodlands Quarry, within $c .30 \mathrm{~cm}$ of the base of the Purley Shale Formation, SM A.57267a. (c, d) Part and counterpart of a pleural segment assigned doubtfully to Callavia. GSM 102127 and GSM 102128; locality as for (a). Scale bars: (a, b) $3 \mathrm{~mm}$; (c-e) $5 \mathrm{~mm}$; (f) $1.5 \mathrm{~mm}$.

(Bonavista Group), and the Brigus Formation. The Cuslett and Fosters Point formations form part of the Camanella baltica Biozone; Brasier, Anderson \& Corfield (1992) showed the FAD of M. phillipsii in Avalonia within the lower part of the Cuslett Formation. Brasier (1984) correlated the Home Farm Member in Nuneaton with the Cuslett Formation of Newfoundland, with faunas typical of the Camanella baltica Biozone, whilst Brasier, Hewitt \& Brasier (1978) correlated the top of the Home Farm Member and the overlying Woodlands Member with the Tommotian Stage of Siberia. However, the Brigus Formation overlies the Fosters Point Formation and lies within the Callavia broeggeri Biozone and this indicates that M. phillipsii may range higher in Newfoundland than in England.

The species Micromitra labradorica (Billings), which is distinguished from M. phillipsii in lacking the characteristic knob on the ventral valve and having a high arched beak, is younger, and appears more characteristic of the Callavia Biozone (Cobbold, 1921;
Brasier, 1989; Hinz, 1987), at which level it occurs in the Cambrian succession of Shropshire (see Fig. 1). It has, however, not been recovered from the Cambrian succession of Warwickshire.

\section{Stratigraphic significance of the bentonite}

Trilobite fragments from levels near the base of the Purley Shale Formation (Figs 1, 4) appear to correlate to a level low in Stage 3 of the Cambrian, corresponding to some part of the Atdabanian of the Siberian successions, but their biozonal level remains doubtful. A fauna some $66 \mathrm{~m}$ above the base of the Purley Shale Formation with Serrodiscus bellimarginatus and Strenuella sabulosa is correlated with the sabulosa Biozone, which is treated as the base of Stage 4 of the Cambrian by Rushton et al. (2011). There is no closer biostratigraphical control on the upper biozonal limit for the bentonite. Therefore, based on palaeontological information from the local succession, the bentonite 
is not older than the latest parts of the Camenella Biozone (Fig. 1), but could be somewhat younger, especially if, as seems likely, there is a significant time gap represented by the non-sequence between the Home Farm Member and the Woodlands Member; the bentonite is not younger than the sabulosa Biozone. However, it is likely that the bentonite age is nearer the earlier part of Series 2, within the Fallotaspis or Callavia trilobite Biozone, rather than nearer the top of that interval (Fig. 1) as this is supported by radiometric ages from Shropshire and Pembrokeshire for strata near the top and base of Stage 3 respectively (Fig. 1; see also Harvey et al. 2011).

The age of $517.22 \pm 0.31 \mathrm{Ma}$ for the lower part of the Purley Shale Formation suggests that the deepening of marine lithofacies in Warwickshire postdates the commencement of the global eustatic sea level rise interpreted for the Browns Pond dysoxic interval of the Laurentian succession (Landing, 2012). In the approximately equivalent Cambrian interval in Shropshire, the Lower Comley Sandstone succession is marine from the level of the late Camenella Biozone through to the Callavia Biozone, its earliest trilobite being referable possibly to Fallotaspis or Kjerulfia (see Bergström, 1973). The equivalent stratigraphic interval in South Wales is represented by the unfossiliferous Caerbwdy Sandstone Formation, which is interpreted to be the product of deltaic deposition (Loughlin \& Hillier, 2011). The bentonite horizon at Woodlands Quarry therefore appears to date a local marine transgression in the Nuneaton area.

\section{Conclusions}

Zircons from a bentonite near the base of the Purley Shale Formation in the Nuneaton area, Warwickshire, provide $\mathrm{a}^{206} \mathrm{~Pb} /{ }^{238} \mathrm{U}$ age of $517.22 \pm 0.31 \mathrm{Ma}$, the first radiometric age for the Cambrian succession of the Midland Microcraton and important for constraining the chronology of the earliest occurrence of trilobites in this region of Avalonia. The first occurrence of trilobites in the Purley Shale Formation is somewhat later than the trilobite fragments recovered from the Caerfai Bay Shales Formation of Pembrokeshire (see Siveter \& Williams, 1995; Harvey et al. 2011) and this is consistent with the appearance of trilobites in the Warwickshire succession being associated with a local marine transgression and a more open marine shelf setting. The new bentonite date provides an additional chronological control on the interval assignable to the Eofallotapsis and Callavia biozones of Cambrian Stage 3.

Acknowledgements. We thank the quarry owner Mr Ian Brown for access to Woodlands Quarry. We are very grateful to Dr Ed Landing (New York State Museum) for detailed discussion on Cambrian stratigraphy. We thank Matt Riley (Sedgwick Museum, Cambridge University) and Louise Neep and Paul Shepherd (British Geological Survey) for making specimens in their care available for study, and Natural England for funding the clearance work supervised by Alan F. Cook and Anton Irving in February 2011. This research was supported by NERC Isotope Geosciences Facilities Steering Committee grant IP/1124/0509.

\section{References}

Bergström, J. 1973. Classification of olenellid trilobites and some Balto-Scandian species. Norsk Geologisk Tidsskrift 53, 283-314.

BRASIER, M. D. 1984. Microfossils and small shelly fossils from the Lower Cambrian Hyolithes Limestone at Nuneaton, English Midlands. Geological Magazine 121, 229-53.

BRASIER, M. D. 1986. The succession of small shelly fossils (especially conoidal microfossils) from English Precambrian-Cambrian boundary beds, Geological Magazine 123, 237-56.

Brasier, M. D. 1989. Sections in England and their correlation. In The Precambrian-Cambrian Boundary (eds J. W. Cowie \& M. D. Brasier), pp. 82-104. Oxford University Press.

Brasier, M. D., ANDERson, M. M. \& CorfIEld, R. M. 1992. Oxygen and carbon isotope stratigraphy of early Cambrian carbonates in southeastern Newfoundland and England. Geological Magazine 129, 26579.

Brasier, M. D., Hewitt, R. A. \& Brasier, C. J. 1978. On the Late Precambrian - Early Cambrian Hartshill Formation of Warwickshire. Geological Magazine 115, 21-36.

Bridge, D. McC., CARney, J. N., LAWLEY, R.S. \& Rushton, A. W. A. 1998. Geology of the Country Around Coventry and Nuneaton. Memoir of the British Geological Survey, sheet 169 (England and Wales). London: The Stationery Office, $185 \mathrm{pp}$.

CobBold, E. S. 1919. Cambrian Hyolithidae, etc., from Hartshill in the Nuneaton district, Warwickshire. Geological Magazine (Decade 6) 6, 149-58, pl. 4.

CoBbold, E. S. 1921. The Cambrian horizons of Comley (Shropshire) and their Brachiopoda, Pteropoda, Gasteropoda, etc. Quarterly Journal of the Geological Society, London 76, 325-86.

Cocks, L. R. M. 2008. A Revised Review of British Lower Palaeozoic Brachiopods. Monograph of the Palaeontographical Society, vol. 161, no. 629, 276 pp, $10 \mathrm{pls}$.

EAstwood, T., Gibson, W., CANTRILl, T. C. \& WhitehEAD, T. H. 1923. The Geology of the Country Around Coventry. Memoir of the Geological Survey of Great Britain, sheet 169 (England and Wales). London: HMSO, $149 \mathrm{pp}$

Harvey, T. H. P., Williams, M., Condon, D. J., Wilby, P. R., Siveter, D. J., Rushton, A. W. A., LenG, M. J. \& GABBOTT, S. 2011. A refined chronology for the Cambrian succession of southern Britain. Journal of the Geological Society, London 168, 705-16.

HINZ, I. 1987. The Lower Cambrian microfauna of Comley and Rushton, Shropshire/England. Palaeontographica Abt A198, 41-100, 15 pls.

HoLL, H. B. 1865. On the geological structure of the Malvern Hills and adjacent districts. Quarterly Journal of the Geological Society, London 21, 72-102.

ILlING, V. C. 1913. Recent discoveries in the Stockingford Shales near Nuneaton. Geological Magazine (Decade 5) 10, 452-3.

JAFFEY, A. H., FlynN, K. F., GLENDENIN, L. E., BENTLEY, W. C. \& Essling, A. M. 1971. Precision measurement 
of half-lives and specific activities of ${ }^{235} \mathrm{U}$ and ${ }^{238} \mathrm{U}$. Physics Reviews C4, 1889-906.

LANDING, E. 1991. Upper Precambrian through Lower Cambrian of Cape Breton Island: faunas, paleoenvironments, and stratigraphic revision. Journal of Paleontology 65, 570-95.

LANDING, E. 1995. Upper Placentian-Branchian Series of mainland Nova Scotia (middle-upper Lower Cambrian): faunas, paleoenvironments, and stratigraphic revision. Journal of Paleontology 69, 475-95.

LANDING, E. 1996. Avalon: insular continent by the latest Precambrian. Geological Society of America, Special Paper 304, 29-63.

LANDING, E. 2012. Time-specific black mudstones and global hyperwarming on the Cambrian-Ordovician slope and shelf of the Laurentia palaeocontinent. Palaeogeography, Palaeogeoclimatology, Palaeoecology 3678, 256-72.

LANDING, E. \& BenUS, A. P. 1988. Stratigraphy of the Bonavista Group, south-eastern Newfoundland: growth faults and the distribution of the sub-trilobitic Lower Cambrian. In Trace Fossils, Small Shelly Fossils, and the Precambrian-Cambrian Boundary (eds E. Landing, G. M. Narbonne \& P. Myrow), pp. 59-71. Bulletin of the New York State Museum no. 463.

LAnding, E., Bowring, S. A., DaVideK, K. L., Westrop, S. R., Geyer, G. \& Heldmaier, W. 1998. Duration of the Early Cambrian: U-Pb ages of volcanic ashes from Avalon and Gondwana. Canadian Journal of Earth Sciences 35, 329-38.

Loughlin, J. D. \& HiLlieR, R. D. 2011. Early Cambrian Teichichnus-dominated ichnofabrics and palaeoenvironmental analysis of the Caerfai Group, Southwest Wales, UK. Palaeogeography, Palaeoclimatology, Palaeoecology 297, 239-51.

MatLey, C. A. 1902. On the Cambrian brachiopods of the Malvern Hills. Quarterly Journal of the Geological Society, London 58, 135-49.

MATTINSON, J. M. 2005. Zircon U-Pb chemical abrasion ("CA-TIMS") method: combined annealing and multistep partial dissolution analysis for improved precision and accuracy of zircon ages. Chemical Geology 220, 47-66.

PENG, S.-C. \& BABCOCK, L. E. 2008. Cambrian Period. In The Concise Geologic Time Scale (eds J. G. Ogg, G. Ogg \& F. M. Gradstein), pp. 37-46. Cambridge University Press.
Powell, J. H., Glover, B. W. \& Waters, C. N. 2000. Geology of the Birmingham Area. Memoir of the British Geological Survey, Sheet 168 (England and Wales). London: The Stationery Office, $132 \mathrm{pp}$.

PRINGLE, J. 1913. In Summary of Progress of the Geological Survey of Great Britain and the Museum of Practical Geology for 1912, p. 71. London: HMSO.

Rushton, A. W. A. 1966. Cambrian Trilobites from the Purley Shales of Warwickshire. Monograph of the Palaeontographical Society, London no. 511, $55 \mathrm{pp}$.

Rushton, A. W. A. 1974. The Cambrian of Wales and England. In Cambrian of the British Isles, Norden and Spitsbergen (ed. C.H. Holland), pp. 42-122. J. Wiley \& Son.

Rushton, A. W. A., BrÜck, P. M., Molyneux, S. G., Williams, M. \& WoOdCOCK, N. H. 2011. A Revised Correlation of the Cambrian Rocks in Britain and Ireland. Special Report of the Geological Society of London no. 25, 62 pp.

Rushton, A. W. A., Owen, A. W., Owens, R. M. \& PRIGMORE, J. K. 1999. British Cambrian to Ordovician Stratigraphy. Joint Nature Conservation Committee, Geological Conservation Review no. 18 [issued 2000], $435 \mathrm{pp}$.

Schmitz, M. D. \& Schoene, B. 2007. Derivation of isotope ratios, errors, and error correlations for $\mathrm{U}-$ $\mathrm{Pb}$ geochronology using ${ }^{205} \mathrm{~Pb}-{ }^{235} \mathrm{U}-\left({ }^{233} \mathrm{U}\right)$-spiked isotope dilution thermal ionization mass spectrometric data. Geochemistry Geophysics Geosystems 8, doi:10.1029/2006GC001492.

Siveter, D. J. \& WiLliams, M. 1995. An early Cambrian assignment for the Caerfai Group of South Wales. Journal of the Geological Society 152, 221-4.

SMith, J. D. D. \& White, D. E. 1963. Cambrian trilobites from the Purley Shales of Warwickshire. Palaeontology 6, 397-407.

TAYLOR, K. \& Rushton, A. W. A. 1971. The Pre-Westphalian Geology of the Warwickshire Coalfield. Bulletin of the Geological Survey of Great Britain no. 35, [issued 1972], $150 \mathrm{pp}$.

Woodcock, N. 2011. Terranes in the British and Irish Cambrian. In A Revised Correlation of the Cambrian Rocks in Britain and Ireland (eds A. W. A. Rushton, P. M. Brück, S. G. Molyneux, M. Williams \& N. H. Woodcock), pp. 16-20. Special Report of the Geological Society of London no. 25. 